\title{
Two new striking braconid genera (Hymenoptera: Braconidae) from the mid-Cretaceous
}

\section{Burmese amber}

Sergey A. Belokobylskij a, b and Corentin Jouault c, d*

a Zoological Institute Russian Academy of Sciences, St. Petersburg 199034, Russia

${ }^{b}$ Museum and Institute of Zoology Polish Academy of Sciences, Wilcza 64, Warszawa 00-679,

Poland.E-mail:doryctes@gmail.com; https://orcid.org/0000-0002-3646-3459

c Université de Rennes, CNRS, Geosciences Rennes, UMR 6118, F-35000, Rennes, France.

dInstitut de Systématique, Évolution, Biodiversité (ISYEB) Muséum national d'Histoire naturelle, CNRS, Sorbonne Université, EPHE, Université des Antilles, CP50, 57 rue Cuvier 75005 Paris, France.E-mail: jouaultc0@gmail.com; orcid.org/0000-0002-3680-5172

* Corresponding author

\begin{abstract}
Two new peculiar mid-Cretaceous braconid genera, Megalyrhyssalus gen. nov. (type species Megalyrhyssalus clavicornis sp. nov.) and Stephanorhyssalus gen. nov. (type species Stephanorhyssalus longiscapus sp. nov.), are described and illustrated from Burmese amber. According to the particular morphology and wing venation of Megalyrhyssalus gen. nov. a new subfamily Megalyrhyssalinae subfam. nov. is created. The subfamily Seneciobraconinae is synonymised under Protorhyssalinae (syn. nov.). Additionally, a key to the genera of Braconidae having second recurrent vein $(2 \mathrm{~m}-\mathrm{cu})$ in forewing is provided.
\end{abstract}


Key words: Cenomanian, Ichneumonoidea, Eoichneumoninae, Megalyrhyssalinae, taxonomy

\section{Introduction}

The oldest representatives of the family Braconidae are dated back to the Cretaceous and belong to five subfamilies, viz. Aphidiinae Haliday, 1833, Eoichneumoninae Jell \& Duncan,1986, Protobraconinae van Achterberg \& Chen, 2021, Protorhyssalinae Basibuyuk, Quicke \& van Achterberg, 1999 (in Basibuyuk et al., 1999) and Seneciobraconinae Engel \& Huang, 2018 (in Engel et al., 2018) (Brues, 1937; Basibuyuk et al., 1999; Perrichot et al., 2009; Ortega-Blanco et al., 2009, 2011; Belokobylskij, 2012; Engel, 2016; Engel and Wang, 2016; Engel et al., 2017, 2018; Chen et al., 2021). However some previously described Cretaceous genera, viz. Aenigmabracon Perrichot, Nel \& Quicke, 2009; Diorhyssalus Engel, 2016, Eobraconus Rasnitsyn, 1985, Protorhyssalodes Perrichot, Nel \& Quicke 2009, Pyramidibracon van Achterberg \& Chen, 2021 and Rhetinorhyssalus Engel, 2016, have not been clearly assigned to a subfamily and are still treated as incertae sedis (Rasnitsyn, 1983; Perrichot et al., 2009; Engel, 2016; Chen et al., 2021). Nevertheless, two genera recently described from Canadian and Burmese ambers, namely Diorhyssalus and Protorhyssalodes, have been included in the Protorhyssalinae (Chen et al., 2021). Additionally, the Cretaceous genera Magadanobracon Belokobylskij, 2012 and Cretorhyssalus Belokobylskij, 2012, both described from imprint fossil specimens, were preliminary placed in the subfamily Protorhyssalinae (Belokobylskij, 2012). However, it appears that numerous key characters are not preserved in these imprint fossils (especially for Cretorhyssalus). Therefore it is nearly impossible to place them confidently in a precise braconid subfamily. On the contrary, the better preservation of amber fossil specimens allows rather clear observation of many diagnostic characters and suggests more confident placements. 
Brues (1937) described from the Canadian Campanian amber three braconid species in extant genera. One of the latter species, Diospilus allani (Brues, 1973), recently became the type species of a new fossil genus Diorhyssalus (Engel, 2016). The two other species, namely Neoblacus facialis Brues, 1937 and Pygostolus patriarchicus Brues, 1937, need to be re-examined because their descriptions are not sufficient to ensure their previous placements (Belokobylskij, 2012; Chen et al., 2021).

Currently, six genera and species of Braconidae have been found and described from the mid-Cretaceous Burmese amber (Engel, 2016; Engel and Wang, 2016; Engel et al., 2018; Chen et al., 2021): viz. Archaeorhyssalus subsolanus Engel, 2016 (Protorhyssalinae; in Engel and Wang, 2016); Protobracon robusticauda Chen \& van Achterberg, 2021 and Tibialobracon compressicornis Chen \& van Achterberg, 2021 (Protobraconinae); Seneciobracon novalatus Engel et Huang, 2018 (Seneciobraconinae); as well as Rhetinorhyssalus morticinus Engel, 2016 and Pyramidibracon clypeatus Chen \& van Achterberg, 2021 (subfamily incertae sedis).

The former valid family Eoichneumonidae (Jell and Duncan, 1986) was recently included in the Braconidae as undefined rank (incertae sedis) but is sometimes treated as a valid braconid subfamily (Perrichot et al., 2009; Chen et al., 2021). Unfortunately, all the previously described eoichneumonid species were based on imprint specimens and their incomplete preservation makes it difficult to observe many important diagnostic characters such as the complete wing venation (especially for the hind wing) (Jell and Duncan, 1986; Rasnitsyn and Sharkey, 1988; Rasnitsyn et al., 1998). Until now, the presence of a second recurrent vein (2m-cu) in the forewing remains the only diagnostic character to discriminate the fossil specimens of this taxonomic group.

Herein, we describe two new braconid genera and species based on rather well-preserved females from the Kachin mid-Cretaceous Burmese amber. Additionally, we provide a key to the 
braconid genera (described from amber deposits and imprint fossils) possessing a second recurrent vein (2cu-a) in the forewing.

\section{Material and method}

The amber pieces containing the specimens come from the deposits of Noije Bum in the Hukawng Valley $\left(26^{\circ} 29^{\prime}\right.$ N, $96^{\circ} 35^{\prime}$ E), Kachin State, northern Myanmar (see detailed map in Grimaldi and Ross, 2017: fig. 2). Radiometric data established an early Cenomanian age (98.79 $\pm 0.62 \mathrm{Ma}$ ) for Kachin amber, based on zircons from volcanic clastes found within the amberbearing sediments (Shi et al., 2012). Some ammonites found in the amber-bearing bed and within amber corroborate a late Albian-early Cenomanian age (Cruickshank and Ko, 2003; Yu et al., 2019).

The holotype of Megalyrhyssalus clavicornis gen. et sp. nov. is complete and well-preserved while that of Stephanorhyssalus longiscapus gen. et sp. nov. is nearly complete with damaged apex of right antenna, apices of wings, and ovipositor. The amber pieces were polished to facilitate the observation of the specimens using a grinder polisher (Buehler EcoMet 30), a very thin silicon carbide sanding paper (grit size $=7000$ ) and a diamond disk. The specimens were examined and photographed with a Leica MZ APO with an attached Canon EOS 5D Mark II camera. All images are digitally stacked photomicrographic composites of several individual focal planes, which were obtained using Helicon Focus 6.7. The figures were composed with Adobe Illustrator CC2019 and Photoshop CC2019 softwares.

The terminology employed for morphological features, sculpture and body measurements follows Belokobylskij and Maetô (2009). Wing venation nomenclature follows Belokobylskij and Maetô (2009), with the terminology of van Achterberg (1993) shown in parentheses. 
The amber pieces are housed in the amber collection of the Geological Department and Museum of the University of Rennes, France (IGR).

\section{Systematic palaeontology}

Order Hymenoptera Linnaeus, 1758

Suborder Apocrita Gerstaecker, 1867

Superfamily Ichneumonoidea Latreille, 1802

Family Braconidae Nees von Esenbeck, 1811

Subfamily Megalyrhyssalinae subfam. nov.

Type genus: Megalyrhyssalus gen. nov. (Figs 1-3)

Included genus and species. Only Megalyrhyssalus gen. nov.; but the genus Eobraconus Rasnitsyn, 1985 described from an incomplete fossil imprint may also belong to this subfamily.

Diagnosis. Hypoclypeal depression (Figs 2B, 2D) present, but relatively short, approximately same height as clypeus medially. Occipital carina (Fig. 2F) present and distinct. Frons (Fig. 2A) distinctly concave; face high, weakly convex and weakly transverse. Eyes large and glabrous; temples relatively short and strongly narrowed behind eyes. Clypeus (Fig. 2B) truncate ventrally, transverse and distinctly convex. Mandible (Fig. 2A) robust and curved with its upper tooth stout and rounded apically. Antenna (Figs 1, 2D) distinctly but not strongly clavate distally. Pedicel of antenna long, tear-shaped; third antennal segment long and slender, longer than fourth segment, with a distinct basal swelling (possibly homologous with anellus); flagellar segments without distinct elongate sensillae. Notauli, precoxal sulcus and prepectal carina of mesosoma present 
and deeply impressed; postpectal carinae absent (Figs 1, 2C, 2D, 2F). Metapleuron with large irregular areas delineated by coarse carinae. Propodeum with distinct obtuse and flat mediolateral processes, with dorsal areas delineated by coarse carinae that is similar to ichneumonid type of areolation having delineated areola, basal and petiolar areas (the preservation makes difficult further description) (Fig. 2F). In fore wing (Figs 3A, 3B), narrow and obscure opening between developed parastigma and costal vein $(\mathrm{C}+\mathrm{SC})$ present. Radial $(\mathrm{r})$ vein originating from distal third of pterostigma. Second abscissa of metacarp (2-R1) very long, about $1.5 \times$ longer than first abscissa (1-R1). First abscissa of medial (1-SR+M), second radiomedial (r-m), first and second transverse anal (2A and a) veins absent. Second abscissa of medial vein (2-M) weakly sinuate and long. Brachial (subdiscal) cell closed distally by brachial (CU1b) vein, which is much shorter than vein 3-CU1. Hind wing (Figs 3A, 3B) with 3 hamuli. Recurrent (m-cu) and second abscissa of cubital (2-CU) veins absent. First submedial (subbasal) cell large; first abscissa of mediocubital vein $(\mathrm{M}+\mathrm{CU})$ longer than second abscissa (1-M). Legs robust (Figs 1, 2D). All femora thickened and unarmed. Hind coxa without basoventral corner nor tubercle. Hind tibia thickened. Claw simple. First metasomal tergite perhaps with dorsope (unclear). Second and third tergites relatively enlarged, suture between them deep and rather wide (Figs 1, 2J). Ovipositor (Fig. 2E) apex weakly thickened and simple (unarmed), with distal acuminate part long. Visible ovipositor sheath much shorter than metasoma.

\section{Megalyrhyssalus gen. nov.}

urn:1sid:zoobank.org:act:B9FD2DF7-8FE0-4940-9E4F-AF798B8F0FC3

Figs 1-3

Type species: Megalyrhyssalus clavicornis sp. nov. 
Etymology. Name derived from a combination of the genus Megalyra Westwood 1832 and the genus Rhyssalus Haliday, 1833, because this new genus intermingles in its forewing some characters of the families Megalyridae and Braconidae.

Diagnosis. Body (Fig. 1) robust not depressed dorso-ventrally. Head (Figs 2A, 2B, 2F) transverse, not depressed. Occipital carina rough at most part. Vertex weakly concave medially. Ocelli of medium-sized. Frons weakly concave. Eyes very large, and bare. Frons between antennal sockets with a distinct medial wide and rounded protuberance. Clypeal suture deep and distinctly delineate from the convex clypeus. Hypoclypeal depression (Fig. 2B) transverse-oval but rather short. Maxillary palpi long, slender and 6(?)-segmented. Antennae (Figs 1, 2D) slender, mainly filiform, but two apical segments slightly thickened and clavate, without visible sensillae, 15segmented, apical segment $1.6 \times$ longer than penultimate segment. Scape thick, tear-shaped, 1.2 $\times$ longer than pedicel, $0.4 \times$ as long as first flagellar segment, without apical lobe nor basal constriction. Pedicel long, thickened, tear-shaped, $0.8 \times$ as long as scape. Flagellar segments cylindrical, first segment $1.25 \times$ longer than second segment. Apical flagellar segment the thickest, weakly acuminate distally. Mesosoma (Figs 2C, 2D, 2F) short and high. Neck of prothorax short; pronotum dorsally nearly straight. Mesoscutum high and subperpendicularly elevated above pronotum, entirely covered by dense, rather long and erect setae. Notauli deep, narrow, complete and crenulate. Medial longitudinal furrow on mesoscutum absent. Prescutellar depression (scutal sulcus) rather short, curved, sparsely crenulate. Scutellum slightly convex. Precoxal sulcus present, rather narrow, but widened anteriorly, crenulate, running along anterior two-thirds of mesopleuron. Prepectal carina present, coarse and complete. Postpectal carina distinctly sinuate. Metapleuron with a few large areas, delineated by coarse carinae. Propodeum strongly convex, vertically fallen in posterior half, with distinct subpointed flat latero-medial processes, dorsal areas present and distinctly delineated by carinae. Forewing (Figs 3A, 3B) $2.5 \times$ longer than its 
maximal width. Costal cell very short and only present between apex of costal vein and parastigma. Pterostigma narrow and long. Metacarp (1-R1) present, with very long its second abscissa (2-R1); first abscissa (1-R1) $0.6 \times$ as long as pterostigma. Radial (marginal) cell strongly shortened. Radial vein (r) arising almost from posterior third of pterostigma. First radiomedial vein (2-SR) present, second vein (r-m) missing; second radiomedial (submarginal) cell absent. First (r) and second (3-SR) radial abscissae forming obtuse angle, obtuse angle present between second (3-SR) and third (SR1) radial abscissae. First recurrent vein (1m-cu) long, distinctly convergent posteriorly with basal (1-M) vein. First medial abscissa (1-SR+M) absent; discoidal (discal) and first radiomedial (submarginal) cells fused. Nervulus (cu-a) weakly postfurcal and inclivous. Brachial (subdiscal) cell rather short and wide, closed postero-apically by sclerotised and directed forwards short brachial vein (CU1b). Parallel vein (CU1a) arising from posterior one-fifth of apical margin of brachial (subdiscal) cell. Longitudinal anal vein (1-1A) straight or nearly so. Both transverse anal veins (2a and a) absent. Hind wing (Figs 3A, 3B) with three hamuli. Radial vein (1-SR) invisible. Medial (basal) cell narrow, subparallel-sided in distal half. Submedial (subbasal) cell long and wide. First abscissa of mediocubital vein $(\mathrm{M}+\mathrm{CU})$ at least 1.5 $\times$ longer than second abscissa (M). Recurrent vein (m-cu) absent. Second abscissa of cubital vein (2-CU) and transverse first anal vein (2A) absent. Legs (Figs 1, 2D) with tibial spurs formula: 1(?)-2-2. All femora thick, rather short, elongate, oval, and without dorsal protuberance. Fore and middle tibiae thickened, rather short and weakly curved, without visible spines along inner or outer margins. All tibia with sparse stout setae and additional apical spines. Trochanters and trochantelli present and distinctly separate. All tarsi long and with elongate their segments. Fore tarsus $1.6 \times$ longer than fore femur. Hind coxa relatively long, rather thick, without basal petiole, without ventro-basal tubercle nor corner, weakly convex ventrally, about $2.5 \times$ longer than its maximal width, about as long as dorsal part of propodeum. Hind femur thickened, distinctly convex dorsally. Hind tibia long, almost straight and distinctly thickened. Hind tibial spurs rela- 
tively short, distinctly curved, about $0.25 \times$ as long as hind basitarsus. Hind tarsus slender, with long segments; its basitarsus straight, about $0.9 \times$ as long as combined length of second-fifth segments. Tarsal claws maybe with a basal lobe (hidden under the pulvillus or within bubbles). Metasoma (Figs 1, 2J) sessile. First tergite relative long and wide, weakly and evenly convex dorsally (lateral view), nearly straight widened toward apex (subdorsal view), at least partly sculptured, with two dorsal carinae; acrosternite of first segment relatively short. Second and third tergites fused, with deep and wide second suture between them. Second tergite slightly shorter than third one; both feebly sculptured. Lateral creases separated dorsal and lateral sides of tergites (laterotergites) present on second to fourth tergites. Fourth tergite rather long and smooth. Ovipositor (included in the same amber piece but detached from the parasitoid body) (Fig. 2E) medium size, weakly curved downward, weakly widened in its distal third, with low and wide dorsal notch but without ventral serration. Ovipositor sheath slender, about $0.6 \times$ as long as metasoma.

Remarks. Megalyrhyssalus gen. nov. is characterized by a combination of numerous peculiar morphological characters, some rarely present or even unknown in other braconids taxa (including all described fossils). The new genus has claviform antenna with tear-shaped pedicel plus very long and narrow basal segments of flagellum; head with rather narrow hypoclypeal depression; the mesoscutum covered by very dense and almost erect setae; metapleuron with large areas delineated by coarse carinae; the propodeum with distinct and wide flat medio-lateral processes; in the fore wing the radial (marginal) cell is strongly shortened, shorter than pterostigma, the second abscissa of the metacarp (2-R1) is much longer than the first abscissa (1-R1), the short distal costal cell is present, the first medial abscissa $(1-\mathrm{RS}+\mathrm{M})$ and the second radiomedial vein ( $\mathrm{r}-\mathrm{m})$ are absent, the brachial (subdiscal) cell is distally closed by the brachial vein (CU1b), both transverse anal veins ( $2 \mathrm{~A}$ and a) are absent; in hind wing, three hamuli, the submedial (subbasal) cell is large and the recurrent vein (m-cu) is absent. 
Megalyrhyssalus gen. nov. is also superficially similar to Eobraconus Rasnitsyn (Rasnitsyn, 1983, 1985) described from an imprint specimen of Khutel-Khara-Ula deposit in South-East Mongolia (Lower Cretaceous) since having in the latter possibly shortened radial (marginal) cell (with distal part of radial vein (SR1) strongly reduced) and in lacking the second radiomedial vein (r-m) of fore wing. However, the new genus distinctly differs from Eobraconus in possessing antenna weakly claviform with tear-shaped pedicel and very long basal segments of flagellum ( $v s$ filiform, with common shape of pedicel and comparatively short flagellar segments), a propodeum with a distinct medio-lateral processes ( $v s$ without such processes), and forewing radial vein (RS) complete ( $v s$ absent at most part), the first medial abscissa (1-RS+M) absent ( $v s$ present), and the metasoma with the ovipositor relatively long (vs very short).

Notes. The areolation of the propodeum of Megalyrhyssalus gen. nov. is insufficiently visible due to the preservation of the holotype, but it ressembles that of representatives of the family Ichneumonidae (Townes, 1969). According to the photo (Fig. 4G), it is possible to see on propodeum the inversely trapezoid basal area, the subsquared and relatively small areola, and wide hexagonal petiolar area that are all delineated by high carinae. A similar 'type' of propodeal areolation was yet never recorded in the extant or fossil Braconidae (including taxa described from Cretaceous period). Such character additionally suggests and reinforces the separated position (perhaps between Ichneumonidae and Braconidae) of Megalyrhyssalus gen. nov.

\section{Megalyrhyssalus clavicornis sp. nov.}

urn:1sid:zoobank.org:act:026872E8-787D-4F6D-A625-AB8A35E34975

Figs $1-3$ 
Type material. Holotype: female, IGR.BU-025 deposited in Geological Department and Museum of the University of Rennes, France (IGR) (a complete specimen in an amber piece measuring $11 \times 5 \times 3 \mathrm{~mm})$.

Locality and horizont. Noije Bum Hill, Hukawng Valley, Kachin State, Myanmar; upper Albian to lower Cenomanian, mid-Cretaceous.

Etymology. The specific epithet refers to the distinct clavus on the tip of antenna, and is to be treated as an adjective.

Description. Female. Body length $3.3 \mathrm{~mm}$; antenna length $1.9 \mathrm{~mm}$; fore wing length $2.08 \mathrm{~mm}$ and width $0.76 \mathrm{~mm}$; hind wing length $1.51 \mathrm{~mm}$ and width $0.30 \mathrm{~mm}$.

Head maximal height $1.3 \times$ its length (measured medially in lateral view); its maximal width about $2.4 \times$ submedial length (measured in dorso-lateral view). Occiput distinctly concave. Vertex distinctly and sparsely punctate, without striation. Temple short, $0.3 \times$ as long as transverse diameter of eye (dorso-lateral view). Eye large, subvertical, without visible emargination opposite antennal sockets, $1.25 \times$ as high as its maximal width (lateral view). Face rather narrow, nearly as wide as high with clypeus. Clypeus weakly truncate ventrally, $2.5 \times$ wider than its medial height. Malar space short, about $0.15 \times$ as high as eye. Hypoclypeal cavity not high, its width about $2.5 \times$ maximal high.

Antenna slightly shorter than body, segments rather evenly and distinctly shortening toward apex. Scape $1.8 \times$ longer than its maximal width; pedicel $2.3 \times$ longer than its maximal width. First flagellar segment very long, $8.6 \times$ longer than its apical width; second segment $8.3 \times$ longer than its maximal width, $1.1 \times$ longer than third segment. Penultimate segment $3.5 \times$ longer than its width, at least $0.9 \times$ as long as previous segments, $0.55 \times$ as long as apical segment; apical segment the thickest, $5.5 \times$ longer than its maximal width. 
Mesosoma length $1.9 \times$ its height. Pronotum dorsally with oblique medio-lateral carinae. Median lobe of mesoscutum with rather distinct but not strong anterolateral corners, weakly but evenly rounded anteriorly, slightly protruding forwards. Mesoscutum with distinct furrows along its lateral margins, almost entirely densely punctate and covered by very dense eyelash-shaped pubescence, $0.9 \times$ as long as its maximal width (measured medially). Scutellum length equal to its anterior width, perhaps with lateral carinae.

Wings. In forewing pterostigma $3.5 \times$ longer than wide. Radial (marginal) cell $1.8 \times$ longer than its maximal width, and about as long as pterostigma. Radial vein (r) $1.2 \times$ longer than the maximal width of pterostigma. Second radial abscissa (3-SR) weakly curved, $1.2 \times$ longer than first abscissa (r), $0.85 \times$ as long as the straight first radiomedial vein (2-SR). United discoidal (discal) and first radiomedial (submarginal) cells $1.9 \times$ longer than its maximal width. First recurrent vein $(1 \mathrm{~m}-\mathrm{cu})$ nearly straight, $3.4 \times$ longer than first radiomedial vein $(2-\mathrm{SR}), 1.1 \times$ longer than the weakly curved basal vein (1-M). First medial abscissa (1-SR+M) straight. Brachial (first subdiscal) cell almost straight anteriorly and posteriorly, $2.5 \times$ longer than wide. Hind wing about $5.0 \times$ longer than its maximal width. Submedial (subbasal) cell $3.5 \times$ longer than its maximal width.

Legs. Fore femur thickened, $3.7 \times$ longer than its maximal width; middle femur weakly thickened, $5.4 \times$ longer than maximal width. Hind femur $3.2 \times$ longer than its maximal width. Hind tibia $7.7 \times$ longer than its maximal width, $1.4 \times$ longer than hind femur. Hind tarsus slender and long, $1.1 \times$ longer than hind tibia; its second segment $0.3 \times$ as long as basitarsus, $1.2 \times$ longer than fifth segment (without pretarsus).

Metasoma $1.4 \times$ longer than metasoma, $0.9 \times$ as long as the combined length of the head and mesosoma. First tergite long, $1.5 \times$ longer than second tergite (lateral view), $1.2 \times$ longer than 
propodeum. Second tergite $0.9 \times$ as long as its basal width, and $0.9 \times$ as long as third tergite; third tergite $1.5 \times$ longer than fourth tergite.

Colour. Body mainly black to dark brown; mesosoma laterally and ventrally reddish brown. Antenna dark brown entirely. Legs mainly dark brown to black, all tibiae and tarsi reddish brown to dark reddish brown. Ovipositor sheath brown entirely. Wings faintly and almost entirely infuscate, with mainly brown veins; pterostigma brown, partly paler.

Male. Unknown.

Subfamily incertae sedis.

Stephanorhyssalus gen. nov.

urn:Isid:zoobank.org:act:8E711504-86DE-486B-B397-CDDF76256692

Figs 4, 5

Type species: Stephanorhyssalus longiscapus sp. nov.

Etymology. Name derived from a combination of the genus names Stephanus Jurine, 1807 and the genus Rhyssalus Haliday, 1833, because this new genus intermingles the morphology of taxa belonging to the Stephanidae and the Braconidae.

Diagnosis. Head (Figs 5B, 5C) not depressed, rounded (lateral view). Ocelli medium-sized. Eyes very large, occupying nearly all the head lateral surface. Occipital carina well developed, present laterally and less marked medio-dorsally; below fused with hypostomal carina. Hypostomal flange wide and distinct. Hypoclypeal depression rather developed. Maxillary palpi very long, six-segmented, apical four segments very long and slender. Antennae (Fig. 4A) slender, 
almost filiform, without visible sensilla. Scape narrow and very long, ca. $0.8 \times$ as long as first flagellar segment, without apical lobe nor basal constriction, its ventral margin (lateral view) almost as long as dorsal margin. Pedicel long, about $0.6 \times$ as long as scape. First flagellar segment cylindrical, $1.3 \times$ longer than second segment. Subapical segments relatively long. Apex of apical-most segment slightly acuminate. Mesosoma (Figs 4A, 5B) weakly depressed and elongate. Neck of prothorax short; pronotum weakly convex dorsally. Mesoscutum rather distinctly and convexly elevated above pronotum. Notauli distinct (deeply impressed) and complete (reaching posterior margin of mesoscutum). Scutellum feebly convex. Prepectal carina present and complete. Propodeum weakly convex; lateral tubercles absent. Forewing (Figs 4A, 4B) with distinct and short costal cell located distally between costal vein and parastigma. Pterostigma wide and long. Metacarp (1-R1) present. Radial vein (r) arising near pterostigma mid-length. Both radiomedial veins (2-SR and r-m) present. Second radiomedial (submarginal) cell short. First (r) and second (3-SR) radial abscissae forming an obtuse angle. First recurrent vein (1m-cu) distinctly antefurcal, subparallel with basal (1-M) vein. Present rather distinct second recurrent vein (2mcu) with median bulla. Nervulus (cu-a) strongly postfurcal and inclivous. Discoidal (discal) cell petiolate anteriorly, petiole (1-SR) rather short. Parallel vein (CU1a) arising from posterior third of apical margin of brachial (subdiscal) cell. Brachial (subdiscal) cell rather short and wide, closed postero-apically by long, sclerotised and subperpendicular brachial vein (CU1b). Longitudinal anal vein (1-1A) nearly straight basally but distinctly curved inwards medially. First transverse anal vein (2a) absent; second transverse anal vein (a) present and distinctly coloured. Hind wing (Figs 4A, 4B) with radial vein (SR) arising from costal vein (2-SC+R) closely to basal vein (1r-m). Radial (marginal) cell without additional transverse vein (r). Medial (basal) cell rather distinctly widened towards apex. Submedial (subbasal) cell long. First abscissa of mediocubital vein $(\mathrm{M}+\mathrm{CU})$ more than twice longer than second abscissa $(\mathrm{M})$. Recurrent vein $(\mathrm{m}-\mathrm{cu})$ absent. Second abscissa of cubital vein (2-CU) present and arising from posterior one-fifth of nervellus 
(cu-a), closely to vein 1-1A. Transverse first anal vein (2A) absent. Femora of all legs (Figs 4A, 5A) relatively short and thick. Tibial spurs formula 1-2-2. Fore and middle femora thick and large, with low and wide medio-dorsal lump. Fore tibia thickened, claviform, as long as fore femur. Fore tarsus $1.1 \times$ longer than fore tibia. Middle coxa rather large, $0.7 \times$ as long as hind coxa. Middle tibia with vertical row of strong spines on its outer side and at least three additional spines on distal inner margin. Segments of middle tarsus relatively long and slender, apical inner bristles of its fifth segment distinct. Hind coxa long, rather thick, with narrow basal petiole, without ventro-basal tubercle nor corner, weakly convex ventrally, almost $3.0 \times$ longer than their maximal width, slightly longer than propodeum. Hind femur thick, distinctly convex dorsally. Hind tibia narrow basally and distinctly widening at most part, its sides subparallel, with four spines on distal inner margin. Hind tibial spurs short, weakly curved, ca. $0.5 \times$ as long as hind basitarsus. Hind tarsus thickened, with rather short segments; its basitarsus slightly concave, 0.45 $\times$ as long as second-fifth segments combined; fifth segment with distinct inner bristles. Tarsal claws short, curved, thickened, and simple. First metasomal tergite (Figs 4A, 5A) subpetiolate, relative long, distinctly and evenly convex dorsally, with lateral carinae; acrosternite of first segment weakly elongate, $0.25 \times$ as long as first tergite. Second and third tergites fused, with shallow second suture. Second tergite basally with sublateral short and basally wide impressions, about as long as third tergite. Lateral creases separated dorsal (tergite) and lateral (laterotergites) sides of tergites present on second to fourth tergites. Hypopygium enlarged, acuminate distally. Ovipositor (Figs 4A, 5A) nearly straight, wide basally and tapering distally.

Distribution. Northern Myanmar (mid-Cretaceous amber: one species).

Notes. Stephanorhyssalus gen. nov. is, at first sight, similar to the middle Cretaceous Aenigmabracon Perrichot, Nel \& Quicke (subfamily incertae sedis; its hind wing venation unknown) (Perrichot et al., 2009; Chen et al., 2021), but distinctly differs from it in having the 
scape, the pedicel and the first flagellar segment very long and narrow (vs short and rather thick), the mesosoma long ( $v s$ short), the middle tibia with vertical row of distinct spines on its outer side (vs without such spines), the hind coxa and trochanter long and rather narrow (vs short and thick), the longitudinal anal vein (1-1A) distinctly sinuate ( $v s$ almost straight) and the first transverse anal vein (2A) absent ( $v s$ present) in forewing.

Besides this, Stephanorhyssalus gen. nov. that resembles to Archaeorhyssalus Engel from the subfamily Protorhyssalinae was also described from Burmese amber (Engel and Wang, 2016). However, Stephanorhyssalus gen. nov. distinctly differs from the latter by its maxillary segments very long ( $v s$ rather short in Archaeorhyssalus), its discoidal (discal) cell of forewing petiolate anteriorly ( $v s$ sessile), its second recurrent vein $(2 \mathrm{~m}-\mathrm{cu})$ present ( $v s$ absent), its longitudinal anal vein (1-1A) distinctly upcurved in the posterior half ( $v s$ not or only weakly curved), its brachial (subdiscal) cell closed apico-posteriorly by the brachial (CU1b) vein (vs open and without CU1b), its first transverse anal vein (2A) absent (vs present), its fore and middle femora strongly widened ( $v s$ weakly widened), its hind tibia distinctly thickened (vs slender), its hind tarsus short and thickened, with a short basitarsus ( $v s$ long and slender, with very long basitarsus), its metasomal hypopygium acuminate distally ( $v s$ truncate).

Remarks. Stephanorhyssalus gen. nov. possesses striking and uncommon morphological characters relative to the other Braconidae, viz. the scape and the pedicel very long and narrow; the middle and the hind coxae long and massive together with long trochanters and trochantelli. The transformed hind tibiae of Stephanorhyssalus gen. nov., which are wide over almost its entire length, perhaps may be structures specializing in the host detection (cf. Vilhelmsen and Turrisi, 2011). Most of the time, similar structures are involved in the detection of the vibrations produced by xylobiotic insects, but also in tracing any hidden host that produce sound (e.g., any endophytous insect larva). 
Stephanorhyssalus longiscapus sp. nov.

urn:1sid:zoobank.org:act:7FC049A2-F96E-4BD4-A24E-BB808DFB18FD

Figs 4, 5

Type material. Holotype: female, IGR.BU-024 deposited in Geological Department and Museum of the University of Rennes, France (IGR) (specimen preserved in a rounded amber piece measuring $10 \times 4 \times 2 \mathrm{~mm})$.

Locality and horizon. Noije Bum Hill, Hukawng Valley, Kachin State, Myanmar; upper Albian to lower Cenomanian, mid-Cretaceous.

Etymology. The specific epithet refers to the elongate scape of the species, and as to be treated as an adjective.

Diagnosis. As for the genus.

Description. Holotype, Female. Body length $2.7 \mathrm{~mm}$; antenna length $2.6 \mathrm{~mm}$.

Head maximal high $1.7 \times$ its length (measured medially in lateral view). Occiput weakly concave. Vertex with rugae at least medially. Temple short. Transverse diameter of eye $4.2 \times$ longer than temple (lateral view). Eye large, subvertical, without anterior emargination, about 1.4 $\times$ higher than wide (lateral view). Face narrow, about $0.8 \times$ as wide as high. Malar space about $0.2 \times$ as high as eye height, $0.9 \times$ as high as basal width of mandible. Clypeus rather short, concave apico-ventrally. Hypoclypeal cavity present, rather wide, not high. Maxillary palpi $1.1 \times$ longer than head height; its penultimate palpomere $1.2 \times$ longer than apical or previous palpomeres. 
Antenna 21-segmented, slightly shorter than body length, its segments evenly shortening toward apex. Scape long and narrow, $1.9 \times$ longer than its maximal width, $1.8 \times$ longer than elongate suboval pedicel. First flagellar segment subcylindrical, $6.5 \times$ longer than its apical width, $1.3 \times$ longer than second segment, which is about $6.0 \times$ longer than its maximal width. Penultimate segments about $5.5 \times$ longer than wide, $1.15 \times$ longer than apical segment.

Mesosoma long, ca. $2.5 \times$ longer than its height. Median lobe of mesoscutum without anterolateral corners, evenly rounded anteriorly, weakly protruding forwards. Mesoscutum in medioposterior third with carinae. Prescutellar depression (scutellar sulcus) rather long, with distinct medial carina.

Wings. Forewing. Pterostigma $3.5 \times$ longer than wide. Radial (marginal) cell mainly missing. Radial vein ( $\mathrm{r}$ ) arising almost from middle of pterostigma, $0.6 \times$ as long as maximal width of pterostigma. Second radial abscissa (3-SR) $1.8 \times$ longer than first abscissa (r), $0.5 \times$ as long as the straight first radiomedial vein (2-SR). Second radiomedial vein (r-m) preserved only anteriorly on very short part. Second radiomedial (submarginal) cell short, perhaps almost as long as its maximal width, almost equal to the wide brachial (first subdiscal) cell. First medial abscissa (1$\mathrm{SR}+\mathrm{M})$ slightly curved. First recurrent vein $(1 \mathrm{~m}-\mathrm{cu})$ almost straight, about $5.0 \times$ longer than second medial vein $(2-\mathrm{SR}+\mathrm{M}), 0.6 \times$ as long as first radiomedial vein $(2-\mathrm{SR})$ and curved basal vein (1-M). Discoidal (discal) cell rather long, $2.0 \times$ longer than its maximal width. Brachial (subdiscal) cell weakly convex anteriorly and posteriorly.

Legs. Fore femur $3.5 \times$ longer than its maximal width. Fore tibia perhaps with vertical row of sparse spines. Middle coxa $2.0 \times$ longer than its maximal width. Hind femur $2.5 \times$ longer than its maximal width. Hind tibia $7.3 \times$ longer than its maximal width. Second segment of hind tarsus $0.5 \times$ as long as basitarsus, $0.7 \times$ as long as fifth segment (without pretarsus). 
Metasoma $0.9 \times$ as long as head and mesosoma combined. First tergite $1.15 \times$ longer than propodeum (lateral view), $1.1 \times$ longer than second and third tergites combined. Perhaps second to sixth tergite smooth but covered with short and dense setae. Fourth and following tergites distinctly projected. Ovipositor perhaps long (its most part missing soon after ovipositor base).

Colour. Body almost entirely dark brown, partly black. Antenna reddish brown, infuscate basally. Legs mainly brown or light reddish brown, distally usually paler, hind coxae black in basal three-quarters, hind femora infuscate. Ovipositor sheath pale brown basally. Wing hyaline, with brownish veins; pterostigma pale brown or yellowish brown.

Male. Unknown.

\section{Key to the braconid genera having a second recurrent vein $(2 \mathrm{~m}-\mathrm{cu})$ in fore wing}

1. First abscissa of medial vein $(1-\mathrm{SR}+\mathrm{M})$ and parastigma in forewing absent Purichneumon Rasnitsyn \& Jarzembowski, 1998

- First abscissa of medial vein $(1-\mathrm{SR}+\mathrm{M})$ and parastigma in forewing present 2

2. First metasomal tergite narrow and long, petiolate; acrosternite of first segment long, longer than half of tergite Apozyx Mason, 1978

- First metasomal tergite wide and usually short, not or only rarely subpetiolate; acrosternite of first segment short, distinctly shorter than half of tergite 3

3. Recurrent vein (m-cu) of forewing interstitial with first radiomedial vein (2SR) Eoichneumon Jell \& Duncan, 1986

- Recurrent vein (m-cu) of forewing postfurcal with first radiomedial vein (2-SR) or rarely antefurcal with it 
4. First abscissa of basal vein (1-SR) of forewing short, $0.2-0.3 \times$ as long as second abscissa (1M)

- First abscissa of basal vein (1-SR) of forewing long, $0.6-0.8 \times$ as long as second abscissa (1M) 6

5. Scape, pedicel and first flagellar segment short and rather thick. Mesosoma short, about $1.7 \times$ longer than its maximal height. Middle tibia without row of spines on its outer side. Hind coxa and trochanter relatively short and thick. Longitudinal anal vein (1-1A) of forewing almost straight. First transverse anal vein (2A) of forewing present Aenigmabracon Perrichot, Nel \& Quicke, 2009

- Scape, pedicel and first flagellar segment distinctly or sometimes very long and relatively narrow. Mesosoma long, about $2.5 \times$ longer than its maximal height. Middle tibia with vertical row of distinct spines on its outer side. Hind coxa and trochanter long and relatively narrow. Longitudinal anal vein (1-1A) of forewing distinctly sinuate. First transverse anal vein (2A) of fore wing absent Stephanorhyssalus gen. nov.

6. Nervulus (cu-a) of forewing distinctly antefurcal with basal vein (1-M). First and second metasomal tergites distinctly striate at most part

Baissobracon Rasnitsyn \& Sharkey, 1988

- Nervulus (cu-a) of forewing postfurcal with basal vein (1-M). First and second metasomal tergites without striation 7

7. Recurrent vein (m-cu) of forewing postfurcal with first radiomedial vein (2-SR). First metasomal tergite not as long as its posterior width. Ovipositor distinctly shorter than metasoma Cretobraconus Rasnitsyn \& Sharkey, 1988 
- Recurrent vein (m-cu) of forewing usually antefurcal with first radiomedial vein (2-SR). First metasomal tergite longer than its posterior width. Ovipositor distinctly longer than metasoma Archobraconus Rasnitsyn \& Sharkey, 1988

\section{Discussion}

The presence of a second recurrent vein $(2 \mathrm{~m}-\mathrm{cu})$ in the forewing of taxa belonging to the superfamily Ichneumonoidea is one of the main diagnostic characters to discriminate the large and worldwide distributed family Ichneumonidae Latreille, 1802 as well as the extinct Praeichneumonidae Rasnitsyn, 1983 and former Eoichneumonidae Jell \& Duncan, 1986. Interestingly, some representatives of few ichneumonid subfamilies (in most of the species belonging to the Neorhacodinae Hedicke, 1922 and the Hybrizontinae Blanchard, 1845) this vein is secondarily lost (Tobias, 1963; Kasparyan, 1988; Yu et al., 2016). On the other hand, vein 2m-cu is predominantly absent in the family Braconidae, but as the exception, it appeared in some cases, possibly as 'atavisms' (Tobias and Belokobylskij, 1983; Quicke et al., 2020b). However, the description of the former monotypic family Apozygidae Mason, 1978 which also possesses a vein 2m-cu (Mason, 1978) and which was later transferred as a braconid subfamily Apozyginae (Sharkey and Wahl, 1992; van Achterberg, 1993) clearly shows that the presence of this vein has been retained in some braconid taxa and in some cases the retention seems permanent. This retention was also supported by the descriptions of the braconid fossil genus Aenigmabracon (Cretaceous) and has led to a re-evaluation of the Eoichneumonidae status (Perrichot et al., 2009). The result was its placement in the Braconidae but so far in status incertae sedis (Perrichot et al., 2009) or as subfamily Eoichneumoninae (Chen et al., 2021). The presence of another braconid genus with vein 2m-cu (described herein from the mid-Cretaceous Burmese amber as Stephanorhyssalus gen. nov.), provides additional information and allows us to assume that this second recurrent vein 
$(2 \mathrm{~m}-\mathrm{cu})$ may be a plesiomorphic state found in fossil taxa (Aenigmabracon, Stephanorhyssalus and members of Eoichneumoninae), but also in the rare extant genus Apozyx Mason, 1978 (Apozyginae) and secondary appeared already as 'atavism' in a few forms in the subfamilies Rhyssalinae and Doryctinae (Tobias and Belokobylskij, 1983).

The hind wing venation shows another valuable set of characters to attest of the placement of a specimen among the Braconidae or among the Ichneumonidae: in the braconid hind wing type, the basal vein (1r-m) is located basally to the separation between the radial vein (SR) and the fourth abscissa of the costal vein $(\mathrm{SC}+\mathrm{R} 1)$, whereas in the ichneumonid-type wing this vein is situated opposite or apical to the separation (Wahl and Sharkey, 1993; Chen et al., 2021). Unfortunately, we do not have distinct or complete preservation of these wing venation characters for all the taxa attributed to the Eoichneumoninae (Jell and Duncan, 1986; Rasnitsyn and Sharkey, 1988; Rasnitsyn et al., 1998). On the other side, most of the species described from amber specimens have these structures preserved and can, therefore, be easily verified. For example, the hind wing of braconid-type is present in the two new genera described above (Megalyrhyssalus gen. nov. and Stephanorhyssalus gen. nov.) but not illustrated for the hind wing of Aenigmabracon (Perrichot et al., 2009). An ulterior examination of the type specimen of this enigmatic Cretaceous genus will surely help in understanding the significance of several diagnostic characters, and will also be useful to correct its placement. Similarly, the absence of such information in the relatively 'better preserved' hind wing venation of a few fossil taxa belonging to the Eoichneumoninae does not allow to reliably clarify their phylogenetic relation nor their taxonomic status. However, on the fossil specimen of Cretobraconus mongolensis Rasnitsyn \& Sharkey, 1988, that possess relatively conspicuous hind wing veins (Rasnitsyn and Sharkey, 1988; Rasnitsyn, pers. comm.), the hind wing venation seems to be rather similar to the ichneumonid-type. 
Another undoubtedly interesting character is the presence in the hind wing of fossil braconid species of a second cubital vein (2-CU) arising from nervellus (cu-a) above longitudinal anal vein (1-1A and 2-1A). The occurrence of such vein in some fossil genera (Protorhyssalus Basibuyuk \& Quicke, 1999, Protorhyssalodes Perrichot, Nel \& Quicke, Aenigmabracon Perrichot, Nel \& Quicke, Protorhyssalopsis Ortega-Blanco, Delclós \& Engel, 2011, Archaeorhyssalus Engel, and problematically also in Rhetinorhyssalus Engel) as well as in a few extant taxa (from the subfamilies Acampsohelconinae, Agathidinae, Apozyginae, Meteorideinae and Sigalphinae) is most probably a plesiomorphic state for Braconidae (Chen et al., 2021). This hypothesis is also reinforced by its presence presence in the Praeichneumonidae, most of Ichneumonidae and some Eoichneumoninae. In fact, the vein 2-CU is similarly not developed in other fossil taxa belonging to the subfamily Protobraconinae (Protobracon van Achterberg \& Chen, 2021, Rhetinorhyssalites Engel, Thomas \& Alqarni, 2017 and Tibialobracon van Achterberg \& Chen, 2021), in Seneciobracon Engel \& Huang, 2018 (Seneciobraconinae) nor in Pyramidibracon van Achterberg \& Chen (subfamily incertae sedis). Among the two new genera described in this article, only Stephanorhyssalus gen. nov. retains the vein 2-CU on the hind wing while Megalyrhyssalus gen. nov. seems to show a more advanced wing venation since already lacking this vein.

The status of the recently created subfamily Seneciobraconinae Engel \& Huang, 2018 seems to be quite doubtful. The main diagnostic characters of the subfamily, as listed in Engel and Huang (2018), are: the lack of the second transverse anal vein (a) in the forewing and of the recurrent vein $(\mathrm{m}-\mathrm{cu})$ in the hind wing; the first recurrent vein $(1 \mathrm{~m}-\mathrm{cu})$ of the forewing is distinctly antefurcal to first radiomedial vein (2-SR) (presence of a well-defined vein $2 \mathrm{SR}+\mathrm{M})$; the presence of a distinct area of the costal cell at the apex of the otherwise totally fused costal vein $(\mathrm{C}+\mathrm{SC}+\mathrm{R})$; the occipital carina incomplete (present only near mandibles), and dorsope of the first metasomal tergite absent. 
One of the most obvious character of the Seneciobraconinae is the presence of a vestigial costal cell at the apex of the costal vein $(\mathrm{C}+\mathrm{SC}+\mathrm{R})$ (Engel and Huang, 2018). However, it needs to point that such structure is also presents on several other fossil taxa (e.g. Aenigmobracon, Archaeorhyssalus, and Rhetinorhyssalus) and in the extant Trachypetidae (Quicke et al. 2020a). This character is also common in numerous extant genera of the subfamilies Rhyssalinae, Doryctinae, Rogadinae, Helconinae, Brachistinae, Blacinae, Euphorinae, Homolobinae, Macrocentrinae, Orgilinae, Ichneutinae, Cardiochilinae, Cheloninae etc. Thus, the discussed feature does not have enough taxonomic value to support a genus or a subfamily status.

Numerous other characters used to define the Seneciobraconinae as a subfamily and treated as apomorphies are often recorded in other Cretaceous or extant genera (viz. the vein a in forewing and the vein m-cu in hind wing both absent, or the antefurcal position of the vein $1 \mathrm{~m}$ cu in the forewing), or not always described nor well-preserved for adequate study in fossil specimens (namely condition of the dorsope on the first metasomal tergite), or even misinterpreted, viz., the occipital carina actually present dorsally and laterally but conspicuously separated from ocelli (see: Engel and Huang, 2018: fig. 1). Additionally, it is worth mentioning that the figure of the head (Engel and Huang, 2018: fig. 2A), allows the observation of a relatively short hypoclypeal cavity in Seneciobracon, suggesting the beginning of the formation of this structure in Braconidae (see also similar state in Megalyrhyssalus gen. nov.).

As result, we think that the subfamily is not valid and does not have to be separated from the Protorhyssalinae. Therefore, we propose its synonymisation under Protorhyssalinae (syn. nov.). The latter subfamily currently includes Seneciobracon Engel \& Huang together with the set of genera described from amber deposits as Archaeorhyssalus Engel, Diorhyssalus Engel, Protorhyssalodes Perrichot, Nel \& Quicke, Protorhyssalopsis Ortega-Blanco, Delclós \& Engel, and Protorhyssalus Basibuyuk \& Quicke (Chen et al., 2021) but maybe also the genera Magada- 
nobracon Belokobylskij, 2011 and Cretorhyssalus Belokobylskij, 2011 described from fossil imprints.

The new subfamily Megalyrhyssalinae subfam. nov. is characterized by a combination of plesiomorphic and apomorphic characters. The complete occipital, prepectal and postpectal carinae, presence of notauli and precoxal sulcus and the complete areolation of the propodeum are considered to be plesiomorphic features of the new subfamily, while the antenna apically clavate and with long and tear-shaped pedicel, metapleuron with large areas delineated by coarse carinae, together with reduction of the first abscissa of the medial $(1-\mathrm{SR}+\mathrm{M})$, the second radiomedial $(\mathrm{r}-\mathrm{m})$, the first and the second transverse anal (2A and a) veins in the fore wing as well as the recurrent $(\mathrm{m}-\mathrm{cu})$ and the second abscissa of the cubital (2-CU) veins in the hind wing are apomorphic characters.

Interestingly, most of the 'true' Cretaceous braconids genera do not have a shortened radial (marginal) cell on the forewing or if shortened, this only weakly (unknown in Eobraconus with strongly reduced apical abscissa of radial vein (RS) and widely opened radial (marginal) cell). Whereas among Eoichneumoninae several previously described species belonging to the genera Eoichneumon, Baissobracon, Cretobraconus, and Purichneumon are characterized by different levels of shortening of this cell. The radial (marginal) cell is very distinctly and maximally shortened in Megalyrhyssalus gen. nov (compared to the other fossils). Additionally, $\mathrm{Me}$ galyrhyssalus gen. nov. lacks both the transverse anal veins ( $2 \mathrm{~A}$ and a) in the forewing as well as the second abscissa of the cubital (2-CU) vein in the hind wing. However, these characters are highly variable in the braconids, for example, in representatives of the Protorhyssalinae. The previously discussed veins are all present in Archaeorhyssalus and Protorhyssalus; while only vein ' $\mathrm{a}$ ' and $2 \mathrm{CU}$ are present in Protorhyssalodes; only the vein ' $\mathrm{a}$ ' is present and $2 \mathrm{CU}$ is unknown in Diorhyssalus; 2A and 'a' veins are both absent but 2CU is present in Protorhyssalopsis; 
and finally all these veins are absent in Seneciobracon. Therefore, it is difficult to clearly separate some subfamilies based solely on the presence or absence of these veins. Interestingly, in the other Cretaceous genera described based on amber material and belonging to the subfamilies Protobraconinae and insectae sedis the veins $2 \mathrm{~A}$ and 'a' are always present while $2 \mathrm{CU}$ is absent. The previously mentioned data distinctly testified that these three discussed veins are relatively sporadically distributed in the genera belonging to braconid fossil subfamilies and have to be avoided in the diagnosis of these taxonomic groups.

\section{Concluding remarks}

Two new peculiar genera and one new braconid subfamily are described and illustrated from the mid-Cretaceous amber of Northern Myanmar. These descriptions indicate that not only the braconid but overall the parasitoid diversity is underestimated in the Burmese amber biota. Additionally, the future discoveries of numerous interesting specimens will greatly help in refining and discuss the placement of other Cretaceous braconid genera or species. Stephanorhyssalus gen. nov. possesses a second recurrent vein $(2 \mathrm{~m}-\mathrm{cu})$ in the forewing and morphology (see discussion) similar to that of Aenigmabracon Perrichot, Nel \& Quicke (subfamily incertae sedis) and Archaeorhyssalus (subfamily Protorhyssalinae). The new subfamily Megalyrhyssalinae subfam. nov. was proposed to accommodate the particular morphology of Megalyrhyssalus gen. nov. This new subfamily is inter alia based on the several characters of wing venation: the first abscissa of the medial $(1-\mathrm{SR}+\mathrm{M})$, the second radiomedial $(\mathrm{r}-\mathrm{m})$, the first and the second transverse anal $(2 \mathrm{~A}$ and a) veins of the forewing completely reduced, the recurrent (m-cu) and the second abscissa of the cubital (2-CU) veins of the hind wing absent. To facilitate future work on fossil braconids we also proposed a key to braconid genera (including Eoichneumoninae) which possess a second 
recurrent vein $(2 \mathrm{~m}-\mathrm{cu})$ in the forewing. We hope that it will help to correctly identify and place the future braconid specimens with similar morphological diagnostic characters.

\section{Acknowledgements}

The authors are grateful to Prof. Alexander P. Rasnitsyn (Moscow, Russia) and Prof. André Nel (Paris, France) for their valuable advices during preparation of this MS. We are very thankful to reviewers, Prof. Alexander P. Rasnitsyn, Prof. Cornelis van Achterberg and Prof. Donald L.J. Quicke, for their insightful comments on the manuscript. This work was in part funded by grants provided by the Russian Foundation for Basic Research (project No. 19-04-00027) and the Russian State Research Project No. AAAA-A19-119020690101-6 to SAB.

\section{References}

Basibuyuk, H.H., Rasnitsyn, A.P., van Achterberg, K., Fitton, M.G., Quicke D.L.J., 1999. A new, putatively primitive Cretaceous fossil braconid subfamily from New Jersey amber (Hymenoptera, Braconidae). Zoologica Scripta 28, 211-214. https://doi.org/10.1046/ j.1463-6409.1999.00006.x

Belokobylskij, S.A., 2012. Cretaceous braconid wasps from the Magadan Province of Russia. Acta Palaeontologica Polonica 57, 351-361. http://dx.doi.org/10.4202/app.2010.0120

Belokobylskij, S.A., Maeto, K., 2009. Doryctinae (Hymenoptera, Braconidae) of Japan. Fauna mundi, Vol. 1, Warszawa, Warshawska Drukarnia Naukowa, 806 pp.

Blanchard, E., 1845. Histoire naturelle des insecte leurs moeurs, leurs métamorphoses et leur classification ou Traite elementaire d'entomologie. Tome Premier. Paris, Librairie de F. Didot Freres, $398 \mathrm{pp}$. 
Brues, C.T., 1937. Superfamilies Ichneumonoidea, Serphoidea, and Chalcidoidea. University of Toronto Studies, Geological Series 40, 27-44.

Chen, H.-Y., van Achterberg, C, Pang, H., Liu, J.-X., 2021. Three new genera of Braconidae (Hymenoptera) from mid-Cretaceous amber of northern Myanmar. Cretaceous Research 118, on-line. https://doi.org/10.1016/j.cretres.2020.104669

Cruickshank, R.D., Ko, K., 2003. Geology of an amber locality in the Hukawng Valley, northern Myanmar. Journal of Asian Earth Sciences 21, 441-455. https://doi.org/10.1016/S13679120(02)00044-5

Engel, M.S., Huang, D., Cai, C., Alqarni, A., 2018. A new lineage of braconid wasps in Burmese Cenomanian amber (Hymenoptera, Braconidae). Zookeys 730, 75-86. http://dx.doi.org/ 10.3897/zookeys.730.22585

Engel, M.S., Thomas, J.C., Alqarni, A.S., 2017. A new genus of protorhyssaline wasps in Raritan amber (Hymenoptera, Braconidae). ZooKeys 711, 103-111. https://doi.org/10.3897/ zookeys.711.20709

Engel, M.S., Wang B., 2016. The first Oriental protorhyssaline wasp (Hymenoptera: Braconidae): a new genus and species in Upper Cretaceous amber from Myanmar. Cretaceous Research 63, 28-32. http://dx.doi.org/10.1016/j.cretres.2016.02.012

Gerstaecker, C.E.A., 1867. Beitrag zur Insekten-fauna von Zanzibar, nach dem während der Expedition des Baron v.d. Decken gesammelten Material zusammengestellt. Archiv für Naturgeschichte $33,1-49$.

Grimaldi, D.A., Ross, A.J., 2017. Extraordinary Lagerstätten in amber, with particular reference to the Cretaceous of Burma. In: Fraser, N.C., Sues, H.D. (Eds.), Terrestrial Conservation 
Lagerstätten: Windows into the Evolution of Life on Land. Dunedin Academic Press, Edinburgh, pp. 287-342.

Haliday, A.H., 1833. An essay on the classification of the parasitic Hymenoptera of Britain, which correspond with the Ichneumones minuti of Linnaeus. Entomological Magazine 1, $259-276,333-350$.

Hedicke, H., 1922. Nomina nova. Deutsche entomologische Zeitschrift 1922, 426-428.

Jell, P.A., Duncan, P.M., 1986. Invertebrates, mainly insects, from the freshwater, Lower Cretaceous, Koonwarra fossil bed (Korumburra group), South Gippsland, Victoria. Memoir of the Association of Australasian Palaeontologists 3, 111-205.

Jurine, L., 1807. Nouvelle méthode de classer les Hyménoptères et les Diptères. 1. Hyménoptères. Geneva. J.J. Paschoud. 319 pp.

Kasparyan, D.R., 1988. New taxa of fam. Paxylommatidae (Hymenoptera, Ichneumonoidea) from the Baltic Amber. Trudy Vsesoyuznogo Entomologicheskogo Obshchestva [Proceeding of All-Union Entomological Society] 70, 125-131. (In Russian).

Latreille, P.A., 1802. Histoire naturelle, générale et particulière, des Crustacés et des Insectes. Tome troisiéme, Paris, 468 pp.

Linnaeus, C., 1758. Systema naturce per regna tria naturce, secundum classes, ordines, genera, species, cum characteribus, differentiis, synonymis, locis. Editio decima, reformata. Tomus 1. Salvius, Holmiae IV, p. 824.

Mason, W.R.M., 1978. A new genus, species and family of Hymenoptera (Ichneumonoidea) from Chile. Proceedings of the Entomological Society of Washington 80, 606-610.

Nees von Esenbeck, C.G., 1811. Ichneumonides Adsciti, in Genera et Familias Divisi. Magazin Gesellschaft Naturforschender Freunde zu Berlin 5, 1-37. 
Ortega-Blanco, J., Bennett, D.J., Delclòs, X., Engel, M.S., 2009. A primitive aphidiine wasp in Albian amber from Spain and a Northern Hemisphere origin for the subfamily (Hymenoptera: Braconidae: Aphidiinae). Journal of the Kansas Entomological Society 82, 273-282. https:// doi.org/10.2317/JKES0812.08.1

Ortega-Blanco, J., Declòs, X., Engel, M.S., 2011. A protorhyssaline wasp in Early Cretaceous amber from Spain (Hymenoptera: Braconidae). Journal of the Kansas Entomological Society 84, 51-57. https://doi.org/10.2317/JKES100728.1

Perrichot, V., Nel, A., Quicke, D.L.J., 2009. New braconid wasps from French Cretaceous amber (Hymenoptera, Braconidae): synonymization with Eoichneumonidae and implications for the phylogeny of Ichneumonoidea. Zoologica Scripta 38, 79-88.

doi:10.1111/j.1463-6409.2008.00358.x

Quicke, D.L.J., Austin, A.D., Fagan-Jeffries, E.P., Hebert, P.D.N., Butcher, B.A., 2020a. Recognition of the Trachypetidae stat.n. as a new extant family of Ichneumonoidea (Hymenoptera), based on molecular and morphological evidence. Systematic Entomology 2020. doi:10.1111/ syen. 12426

Quicke, D.L.J., Belokobylskij, S.A., Braet, Y., van Achterberg, C., Hebert, P.D.N., Prosser, S.W.J., Austin, A.D., Fagan-Jeffries, E.P., Ward, D.F., Shaw, M.R., Butcher, B.A., 2020b. Phylogenetic reassignment of basal cyclostome braconid parasitoid wasps (Hymenoptera) with description of a new, enigmatic Afrotropical tribe with a highly anomalous 28S D2 secondary structure. Zoological Journal of the Linnean Society 190, 1002-1019. https://doi.org/10.1093/ zoolinnean/zlaa037

Rasnitsyn, A.P., 1983. Ichneumonoidea (Hymenoptera) from the Lower Cretaceous of Mongolia. Contribution of American Entomological Institute 20, 259-265. 
Rasnitsyn, A.P., 1985. Eobraconus, a substitute name for Eobracon Rasnitsyn (Hymenoptera, Braconidae). Psyche 92, 163. https://doi.org/10.1155/1985/95745

Rasnitsyn, A.P., Jarzembowski, E.A., Ross, A.J., 1998. Wasps (Insecta: Vespida = Hymenoptera) from the Purbeck and Wealden (Lower Cretaceous) of southern England and their biostratigraphical and palaeoenvironmental significance. Cretaceous Research 19, 329-391. https:// doi.org/10.1006/cres.1997.0114

Rasnitsyn, A.P., Sharkey, M., 1988. New Eoichneumonidae from early Cretaceous of Siberia and Mongolia (Hymenoptera: Ichneumonoidea). In: Gupta, V.K., (Ed.). Advances in Parasitic Hymenoptera Research, 169-197.

Sharkey, M.J., Wahl, D.B., 1992. Cladistics of the Ichneumonoidea. Journal of Hymenoptera Research 1, 15-24.

Shi, G.-H., Grimaldi, D.A., Harlow, G.E., Wang, J., Yang, M.-C., Lei, W.-Y., Li, Q.-L., Li, X.-H., 2012. Age constraint on Burmese amber based on U-Pb dating of zircons. Cretaceous Research 37, 155-163. https://doi.org/10.1016/j.cretres.2012.03.014

Tobias, V.I., 1963. Ichneumonidae (Hymenoptera) with a venation type in the fore wings which resembles that in Braconidae. Zoologicheskiy Zhurnal 42, 1513-1522. (In Russian with English summary).

Tobias, V.I., Belokobylskij, S.A., 1983. Aberrant wing venation in Braconidae (Hymenoptera) and its significance in study of the phylogeny of the family. Entomologicheskoe Obozrenie 62, 341-347. (In Russian).

Townes, H., 1969. The genera of Ichneumonidae, Part 1. Memoirs of the American Entomological Institute 11, 1-301. 
van Achterberg, C., 1993. Illustrated key to the subfamilies of the Braconidae (Hymenoptera: Ichneumonoidea). Zoologische Verhandelingen 283, 1-189.

Vilhelmsen, L.B., Turrisi, G.F., 2011. Per arborem ad astra: morphological adaptations to exploiting the woody habitat in the early evolution of Hymenoptera. Arthropod Structure \& Development 40, 2-20. https://doi.org/10.1016/j.asd.2010.10.001

Wahl, D.B., Sharkey, M.J., 1993. Chapter 10. Superfamily Ichneumonoidea. In: Goulet, H., Huber, J.T., (Eds.), Hymenoptera of the World: an identification guide to families. Agriculture Canada Publication, Ottawa: 358-509.

Westwood, J.O., 1832. In: Griffith, E. Supplement on the Hymenoptera, 389-576. In: Cuvier, G., Animal Kingdom, Class Insecta. Whittaker, Treacher and Co, London, 796 pp.

Yu, D.S.K., van Achterberg, C., Horstmann, K., 2016. Taxapad 2016, Ichneumonoidea 2015. Taxapad database on flash-drive, Ottawa, Canada.

Yu, T.-T., Kelly, R., Mu, L., Ross, A., Kennedy, J., Broly, P., Xiai, F.-Y., Zhang, H.-C., Wang, B., Dilcher, D., 2019. An ammonite trapped in Burmese amber. Proceedings of the National Academy of Sciences of the United States of America 116, 11345-11350. https://doi.org/ $10.1073 /$ pnas. 1821292116. 


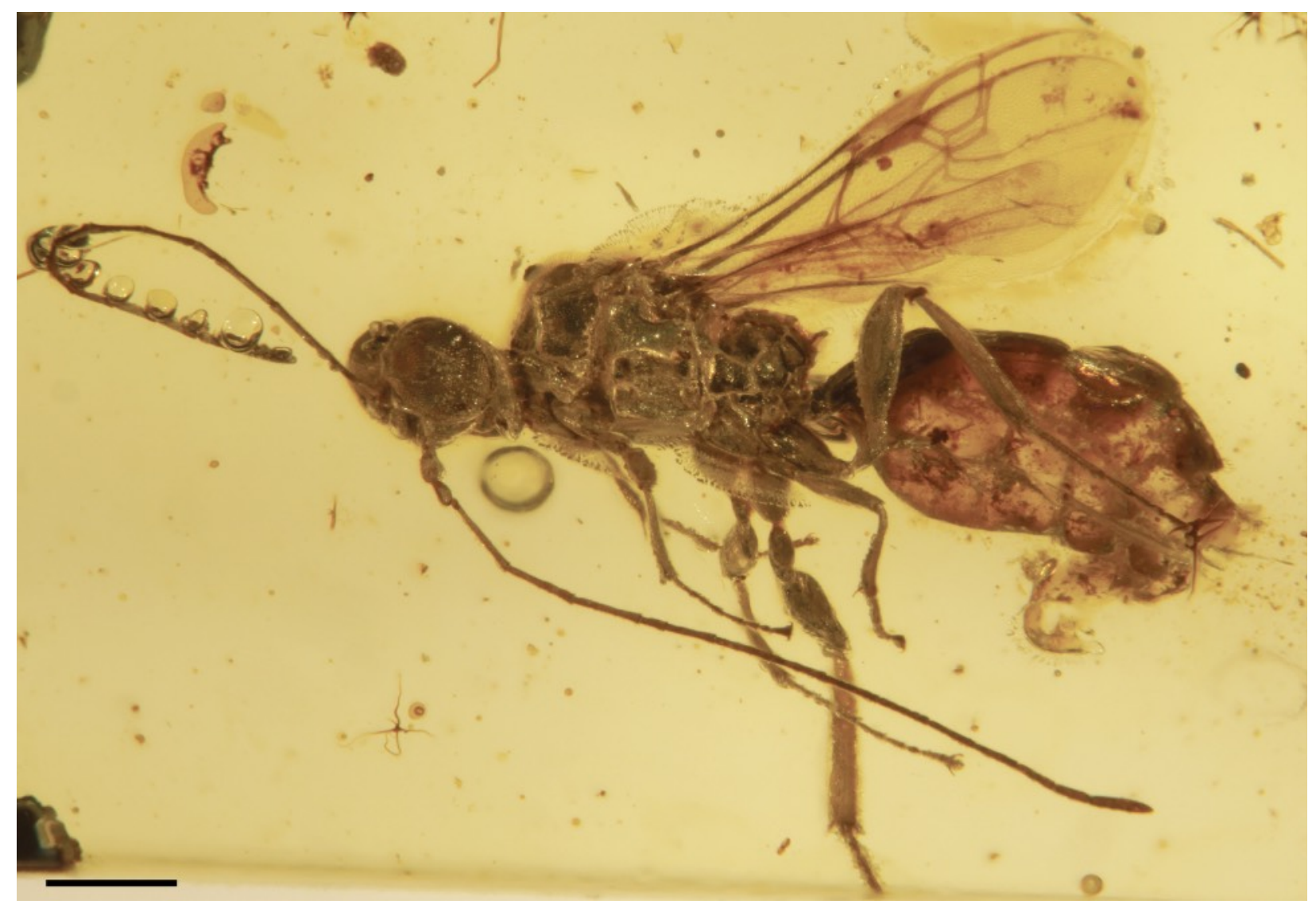

Fig. 1. Megalyrhyssalus clavicornis sp. nov.,, , holotype (IGR.BU-025). Habitus, lateral view. Scale bars: $0.5 \mathrm{~mm}$. 

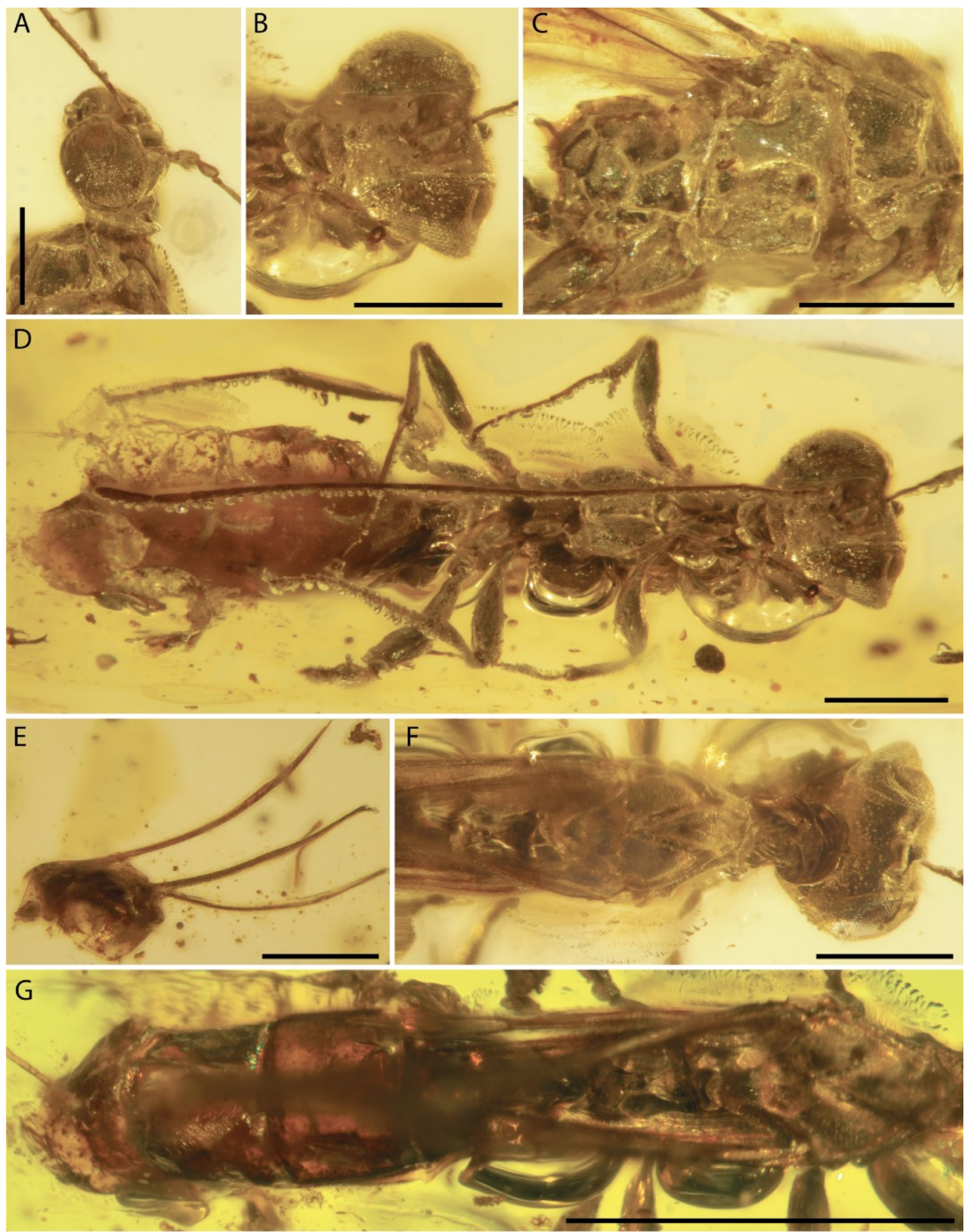

Fig. 2. Megalyrhyssalus clavicornis sp. nov.,, , holotype (IGR.BU-025). A. Head with basal an-

tenna, lateral view; B. Head, front view; C. Mesosoma, lateral view; D. Body, ventral view; E. 
Ovipositor and sheath; F. Mesosoma and head, dorsal view; G. Mesosoma and metasoma, dorsal view. Scale bars: $0.5 \mathrm{~mm}(\mathrm{~A}-\mathrm{F}) ; 1 \mathrm{~mm}(\mathrm{G})$.

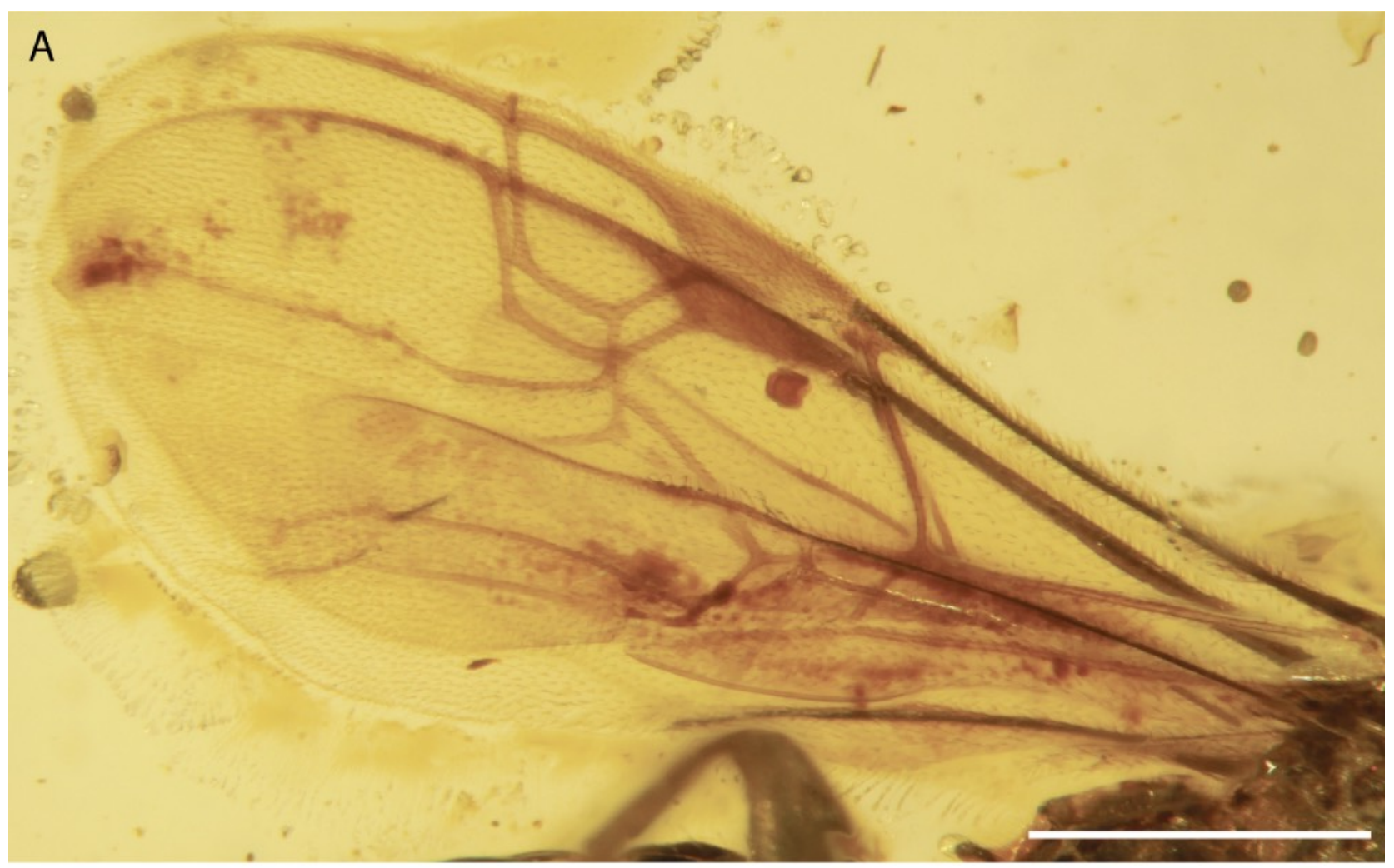

B

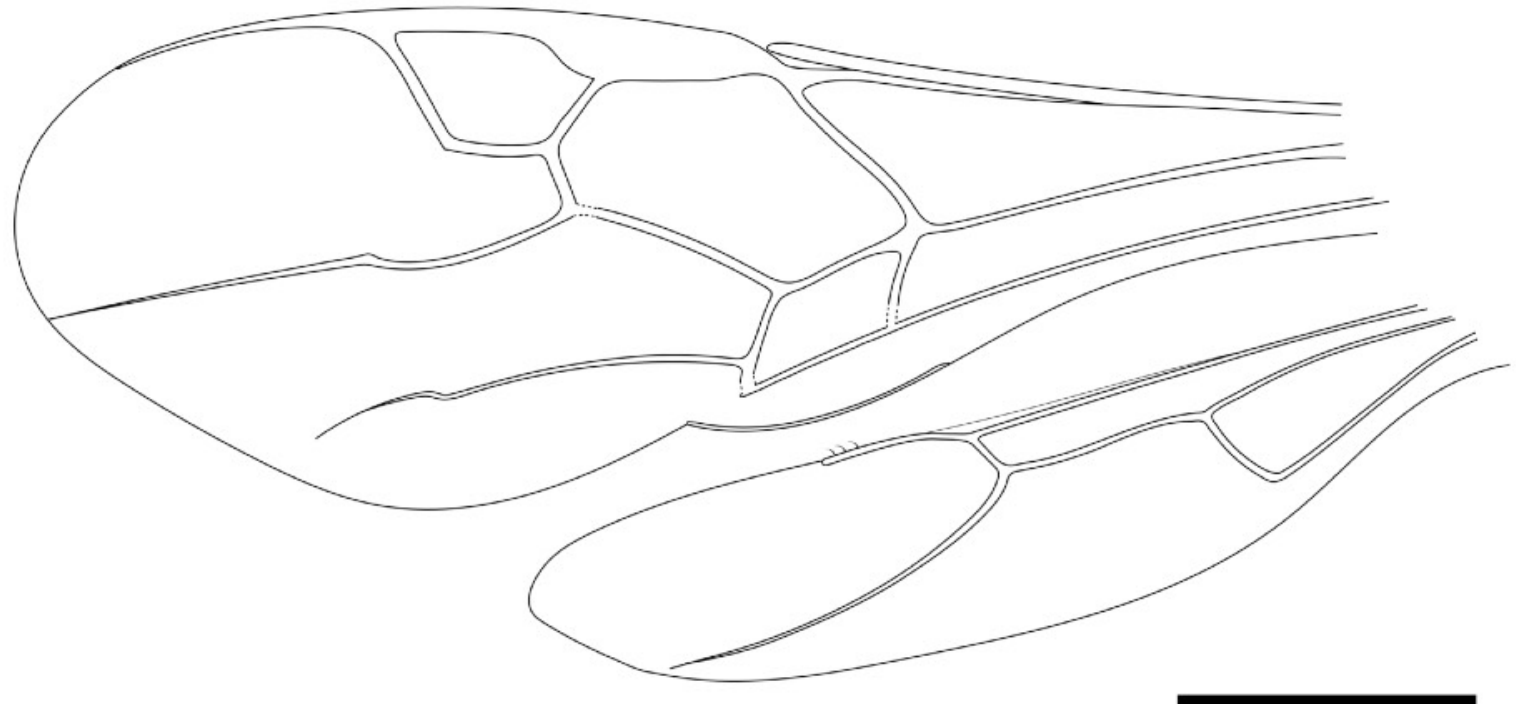

Fig. 3. Megalyrhyssalus clavicornis sp. nov., +, holotype (IGR.BU-025). A. Wings, photo; B. Wings, drawing. Scale bars: $0.5 \mathrm{~mm}$. 

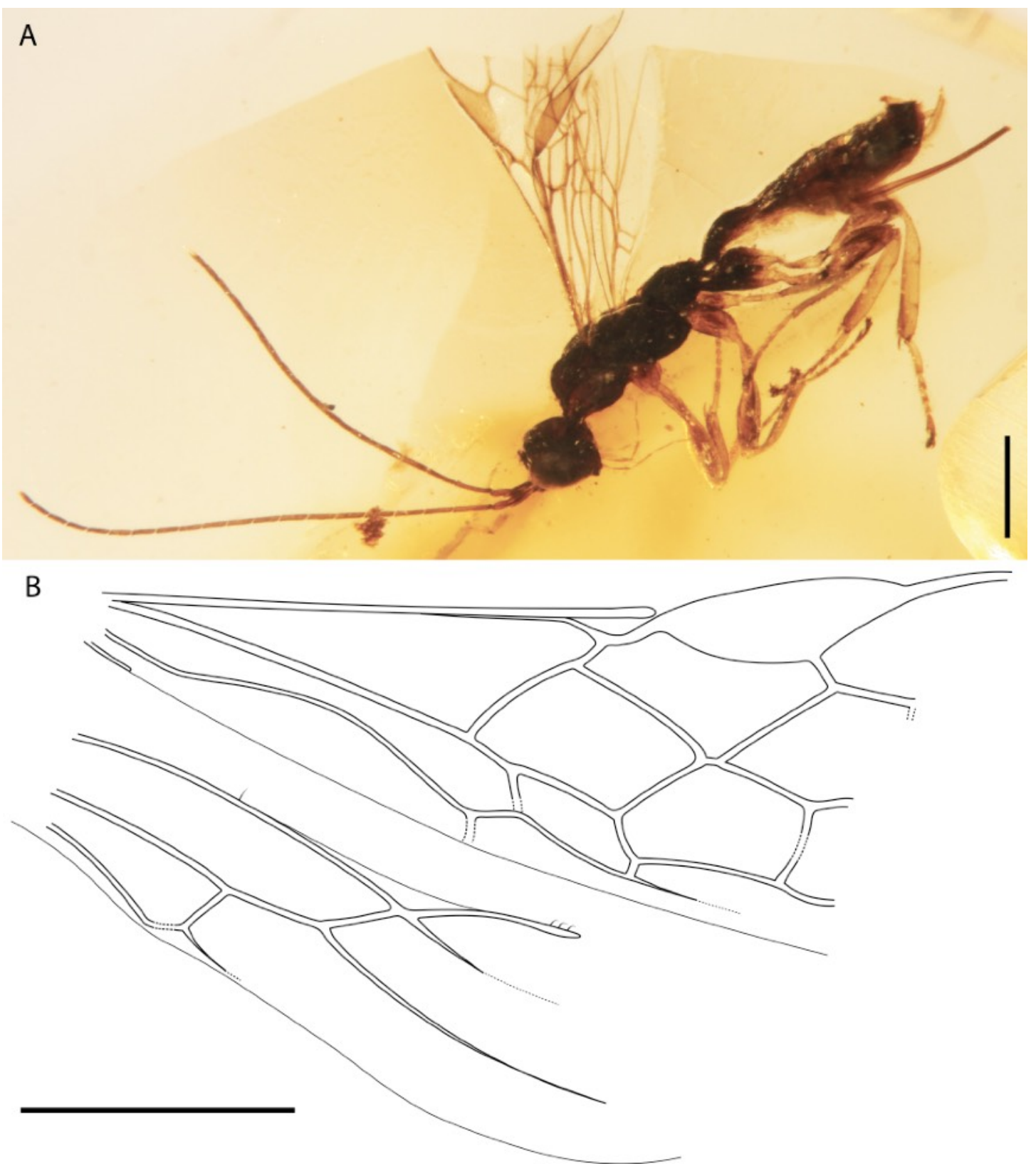

Fig. 4. Stephanorhyssalus longiscapus sp. nov., +, holotype (IGR.BU-024). A. Habitus, lateral view; B. Wings, drawing. Scale bars: $0.5 \mathrm{~mm}$. 


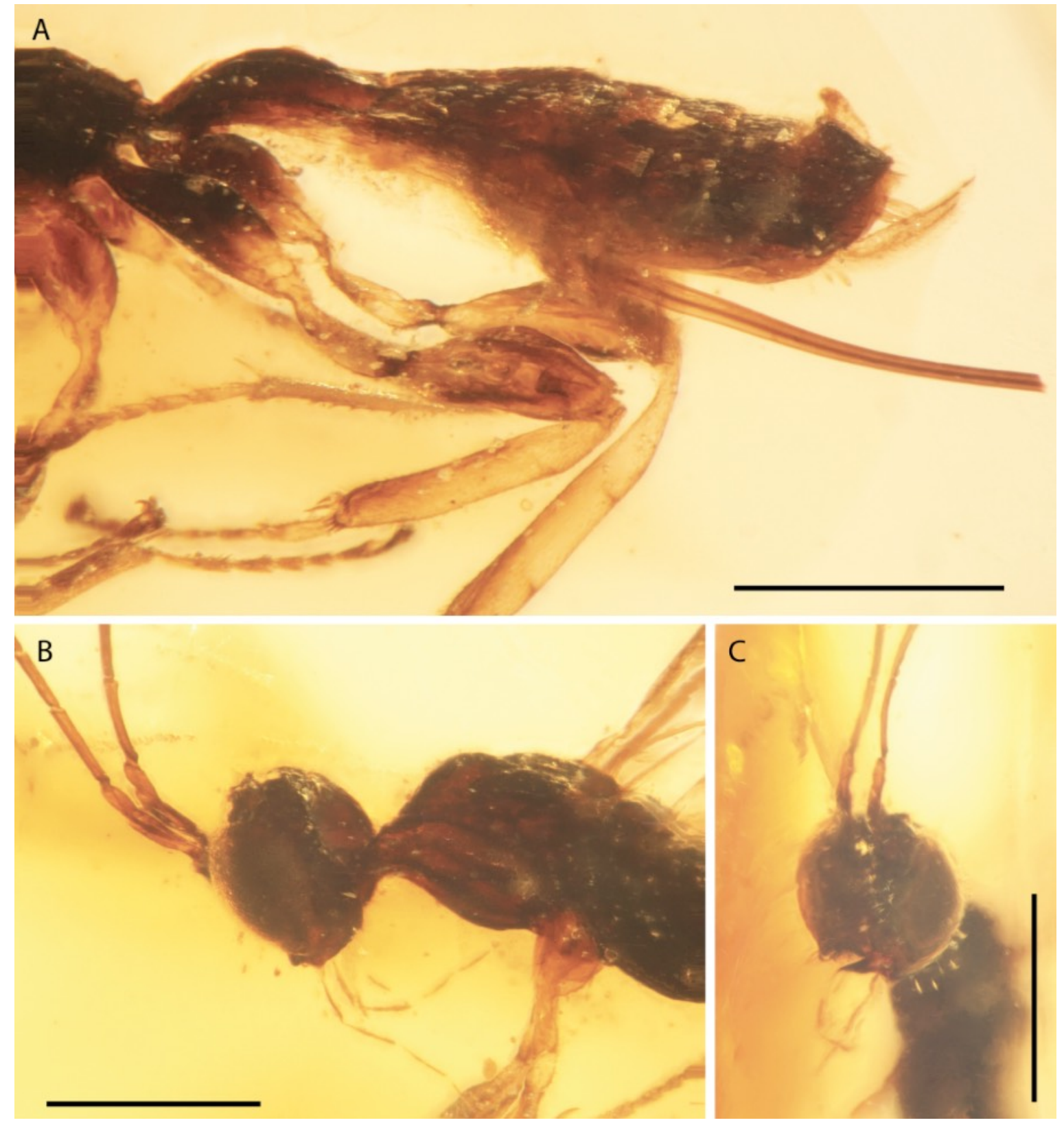

Fig. 5. Stephanorhyssalus longiscapus sp. nov.,, , holotype (IGR.BU-024). A. Metasoma with ovipositor and hind leg, lateral view; B. Head, base of antenna and anterior half of mesosoma, lateral view; C. Head and base of antenna, antero-lateral view. Scale bars: $0.5 \mathrm{~mm}$. 